\title{
Rafael González Fernández, Justiniano, EMPERADOR DE LOS ROMANOS, MADRID, EDITORIAL Síntesis. Temas De historia Antigua 24, 2020, 353 PÁGS. ISBN: 978-84-1357-036-5.
}

\author{
Miguel Pablo Sancho Gómez \\ Universidad Católica de Murcia
}

Nos hallamos ante una monografía cuyo tema nunca deja de ser relevante dada su gran trascendencia: el emperador Justiniano y su mundo. Es marcadamente difícil ofrecer las características principales de una época tan extensa y compleja en una sola obra, pero en este caso se ha logrado el objetivo con creces.

Rafael González Fernández, discípulo aventajado y máximo exponente de la escuela de Antigüedad Tardía iniciada en la Universidad de Murcia por don Antonino González Blanco, es profesor catedrático de Historia Antigua. Sería imposible mencionar o reconocer, aunque fuera brevísimamente, el fecundo y extenso currículo del profesor González Fernández, ya que excedería los límites establecidos para esta reseña. Baste decir que a sus numerosas publicaciones y elogiable labor docente se une la faceta arqueológica, una larga y exitosa trayectoria de por sí, repleta de fecundos logros. En la actualidad es especialmente destacable su puesto de director en el yacimiento de "Los Villaricos" en Mula (Región de Murcia), ya que ofrece, y seguirá ofreciendo en los próximos años, asombrosos descubrimientos que abren nuevas e inesperadas perspectivas en diversos campos de estudio del mundo romano.

En Justiniano, emperador de los romanos, vemos a Rafael González Fernández regresar a los orígenes, puesto que dicho emperador fue objeto de estudio en su brillante tesis doctoral defendida con el mayor éxito en 1990, y que continúa siendo una lectura de gran provecho e interés a día de hoy. El libro se divide en nueve capítulos, tomando especial interés en los logros de Justiniano referentes a legislación, organización estatal y política exterior imperial. La faceta religiosa, esencial en Justiniano, goza por supuesto de merecido y clarificador espacio en la monografía, así como la descripción minuciosa de las numerosas (y como se verá, excesivas) campañas militares imperiales, en un reinado caracterizado a posteriori por la expresión renovatio imperii, que significó un marcado expansionismo militar y la recuperación temporal de las antiguas provincias de Italia y África.

La obra ofrece gran utilidad para el estudiante, dada la extensa presentación de las fuentes literarias del periodo y el acopio de textos que aparecen al final, en una amplia 
y brillante selección. Del mismo modo, su carácter globalizador y la esmerada puesta al día historiográfica llevada a cabo por González Fernández conlleva interés mayúsculo para el investigador o especialista. Además, una acertada tabla cronológica representa una gran ayuda para el lector convencional.

En cualquier caso, llama poderosamente la atención la habilidad mostrada en la presente monografía para bajar al detalle sin perder nunca la panorámica necesaria y la visión de conjunto. Pormenorizadas narraciones de las gestas de Belisario acompañan una soberbia visión de la compleja e inacabada política religiosa de Justiniano, que recuérdese, fue a la vez cabeza del estado y de la Iglesia. El emperador persiguió con anhelo durante toda su dilatada vida la paz y la unidad en el cristianismo, aunque obtuvo pocos frutos en ese campo, y sus esfuerzos denodados resultaron casi siempre estériles.

La gran problemática que representaba para el Imperio la vecindad de los persas (Sasánidas) es también descrita satisfactoriamente; un quebradero de cabeza para no pocos emperadores de Juliano en adelante. Justiniano, ha de afirmarse, logró las primeras grandes victorias contra los persas desde los lejanos tiempos de Caro y Galerio, aunque la paz eterna no fue tal, y a menudo hubo de pagarse cuantiosas sumas de oro a cambio de la tranquilidad en Siria. Pese a que no se trató de una de las guerras expansivas del emperador, quizás hubiera sido más clarificador si se hubiera relatado junto al resto de campañas militares, en el capítulo correspondiente.

Otra de las grandes ideas acertadas es mostrar la abundante recepción de Justiniano (y Belisario, y Teodora) en la posteridad, reflejando su imagen tanto en los tratados históricos de clásicos como Bury o Gibbon como la aparición de los temas justinianeos en la literatura, el teatro, la pintura y el cine hasta la actualidad, en una elevada visión, aderezada por numerosas e interesantes referencias, tan completa y detallada que incluye incluso los videojuegos.

Justiniano, en su grandeza y miserias, yerros y aciertos, contradicciones y creencias, está aquí; actual, cercano y presente como nunca en su trascendencia, gracias al gran esfuerzo y acertado logro de González Fernández. Observamos un monarca devoto, personalísimo y acaparador, que en su deseo por controlar cada faceta de gobierno ejerció en ocasiones una influencia obsesiva sobre sus contemporáneos. Sus logros en materia legal y en la actividad edificadora son imperecederos, pero la excesiva presión a la que sometió los menguados recursos económicos del Imperio Romano de Oriente representaron una desproporcionada carga que originó después muchas y muy negativas consecuencias.

Por último, mencionaremos la elogiable medida de disponer la mayor parte de la inmensa bibliografía utilizada para esta monografía en la página de internet de la editorial (www. sintesis.com), favoreciendo así el ahorro responsable de papel y el respeto y cuidado por el medio ambiente. 